\title{
Flora and fauna diversity in Selangkau forest: A basis for developing management plan of cement industrial complex in East Kalimantan, Indonesia
}

\author{
TIEN AMINATUN ${ }^{1, \boldsymbol{v}}$, RAHARJO ARI SUWASONO ${ }^{2}$, RIZKA APRIANI PUTRI ${ }^{1}$ \\ ${ }^{1}$ Program of Biology, Faculty of Mathematics and Natural Sciences, Universitas Negeri Yogyakarta. Jl. Colombo No 1, Karangmalang, Sleman 55281, \\ Yogyakarta, Indonesia. Tel./fax.: +62-274-548203, "email: tien_aminatun@uny.ac.id \\ ${ }^{2}$ Laboratory of Ecology and Conservation of Tropical Forest Biodiversity, Faculty of Forestry, Universitas Mulawarman. Jl. Penajam, Gunung Kelua, \\ Samarinda 75123, East Kalimantan, Indonesia
}

Manuscript received: 24 August 2021. Revision accepted: 27 September 2021

\begin{abstract}
Aminatun T, Suwasono RA, Putri RA. 2021. Flora and fauna diversity in Selangkau forest: A basis for developing management plan of cement industrial complex in East Kalimantan, Indonesia. Biodiversitas 22: 4555-4565. The management of natural resources for economic development often clashes with environmental protection. That is the case in East Kutai District, East Kalimantan, Indonesia which is faced with competing interests between the development of the cement industry and biodiversity conservation. This study is aimed to identify the diversity of flora and fauna in a forest ecosystem to be developed as a cement industrial complex in the Selangkau Village, Kaliorang Sub-district, East Kutai District, and to provide recommendations for environmental management plans as part of the conservation efforts. A vegetation survey using purposive sampling was performed at four vegetation stages: seedlings, saplings, poles and trees. Analysis was done to examine the diversity, dominance, evenness, richness and importance value indices. The fauna study was conducted by the exploration method to collect data on mammals, birds, amphibians and reptiles. The vegetation study recorded 29 species including Buchanania arborescens Blume which had the highest importance value in all growth stages. One species of tree (Shorea glauca) found in this area is also classified as endangered species with high conservation importance. The fauna study found 42 species of birds, 7 of which are protected, 14 species of mammals, 5 of which are protected and 11 species of amphibians and reptiles. Efforts to save the protected species are necessary in response to the new cement factory construction plan in the study area, for example by reclamation and revegetation using the native plants recorded in this study and by transferring animal species into a new habitat that resembles the initial one.
\end{abstract}

Keywords: Biodiversity, ecosystem, exploration, forest, Kalimantan.

Abbreviations: CSR: Corporate Social Responsibility, D: Density, RD: Relative Density, Dm: Dominance, RDm: Relative Dominance, IVI: Importance Value Index, R: Richness, E: Evenness

\section{INTRODUCTION}

Economic activities through the extraction of natural resources generally have negative impacts on the environment including on biodiversity. The mining sector is one example of extractive economies that causes ecological damages, particularly if mining operation is conducted in forested landscapes (Myroniuk et al. 2020). Mining activities, moreover when conducted using the open-pit mining method, will clear vegetation cover and remove topsoil, leaving the landscape to be open and changing the microclimate of the mined site to be hotter and drier. Therefore, prudent consideration and well planning is needed to minimize the impacts caused by extractive activities, such as mining, on forested landscapes (Potapov et al. 2017).

East Kalimantan, Indonesia is rich with natural resources including quarry mining to develop the cement industry. One area with the potential for the cement industry is Selangkau Village, Kaliorang Sub-district, East Kutai District. The establishment of the cement industry in
East Kalimantan is essential to support the Indonesian Government's plan to moving the national capital from Jakarta to East Kalimantan (Yusriyah et al. 2020). It is also expected that the cement industry will positively impact the economic development of the local community and the East Kalimantan Province (Environmental Impact Assessment Report of PT Kobexindo Cement 2020).

Nonetheless, East Kalimantan (and Borneo in general) holds great biodiversity and is among the global biodiversity hotspots (Budiharta and Meijaard, in press). For example, Ismawan et al. (2015) reported that in the Prevab of the Kutai National Park in East Kalimantan live 22 species of birds from 15 families and six orders. Falah et al. (2013) reported that in the Gunung Beratus Conservation Forest in East Kalimantan, 36 species of medicinal plants were identified from 30 families, which the Dayak Benuaq community has used to treat various ailments. Therefore, there are conflicting interests between economic development versus biodiversity conservation in East Kalimantan, prompting dilemmas in policies and decision making. The development of the cement industry will likely impact the biodiversity in East Kalimantan 
altogether with habitat destruction, the rarity of biodiversity and overexploitation (Harrison et al. 2020 )

Currently, the depletion of natural resources as a negative impact of global economic growth has raised the awareness among the business people to pay more attention to the environment and push them to implement more environmentally friendly practices, although there is still room for improvement to create the best practices for the environment (Purwandani and Michaud 2021). In the context cement industry in East Kalimantan, scientific studies are needed to bridge the gap between the development of the cement industry (along with the mining of limestone quarry) and biodiversity conservation. Besides setting aside forests with high conservation values (Fiqa et al. 2019), post-mined reclamation will be required to recover the landscape to a better condition (Lestari et al. 2019). In this regard, integrated planning when developing the cement industry should consider biodiversity conservation and post-mining reclamation activities to minimize the environmental impacts (Hou et al. 2021). An initial step is by characterization and mapping of the biodiversity as baseline information to develop appropriate conservation strategies (Tripathi et al. 2016). Therefore, this study is aimed to identify the diversity of flora and fauna in the forest ecosystem to be developed as a cement industrial complex in the Selangkau Village, Kaliorang Sub-district, East Kutai District, and to provide recommendations for environmental management plans as part of the conservation efforts.

\section{MATERIALS AND METHODS}

\section{Study area}

This research was conducted in Selangkau Village, Kaliorang Sub-district, East Kutai District, East Kalimantan Province. The area was formerly a limestone hill forest and is planned for a cement factory complex. Vegetation data were sampled at three locations at the coordinates of N $00^{\circ} 47^{\prime} 45.06$ " E 117 $48^{\prime} 03.29^{\prime \prime}$; N $00^{\circ} 48^{\prime} 05.00^{\prime \prime}$ E $117^{\circ} 48^{\prime} 38.30^{\prime \prime}$ and N 0048'22.38' E $117^{\circ} 49^{\prime} 10.38^{\prime \prime}$ (Figure 1).

\section{Procedures}

The tools and materials used in this study were the map of the observation site, machete, compass, measuring tape $(50 \mathrm{~m})$, permanent markers, tally sheet, phi-band, camera trap, binoculars, Global Positioning System (GPS), photo camera, handling tools, lithium battery, and flora identification books (Bodegom et al. 1999; Kessler et al. 1999; Kessler 2000; Sidiyasa 2015; Ngatiman and Budiono 2009), fauna identification books (MacKinnon et al. 2000), Nikon P900 camera with 40-2000 mm lens, and flagging tape.

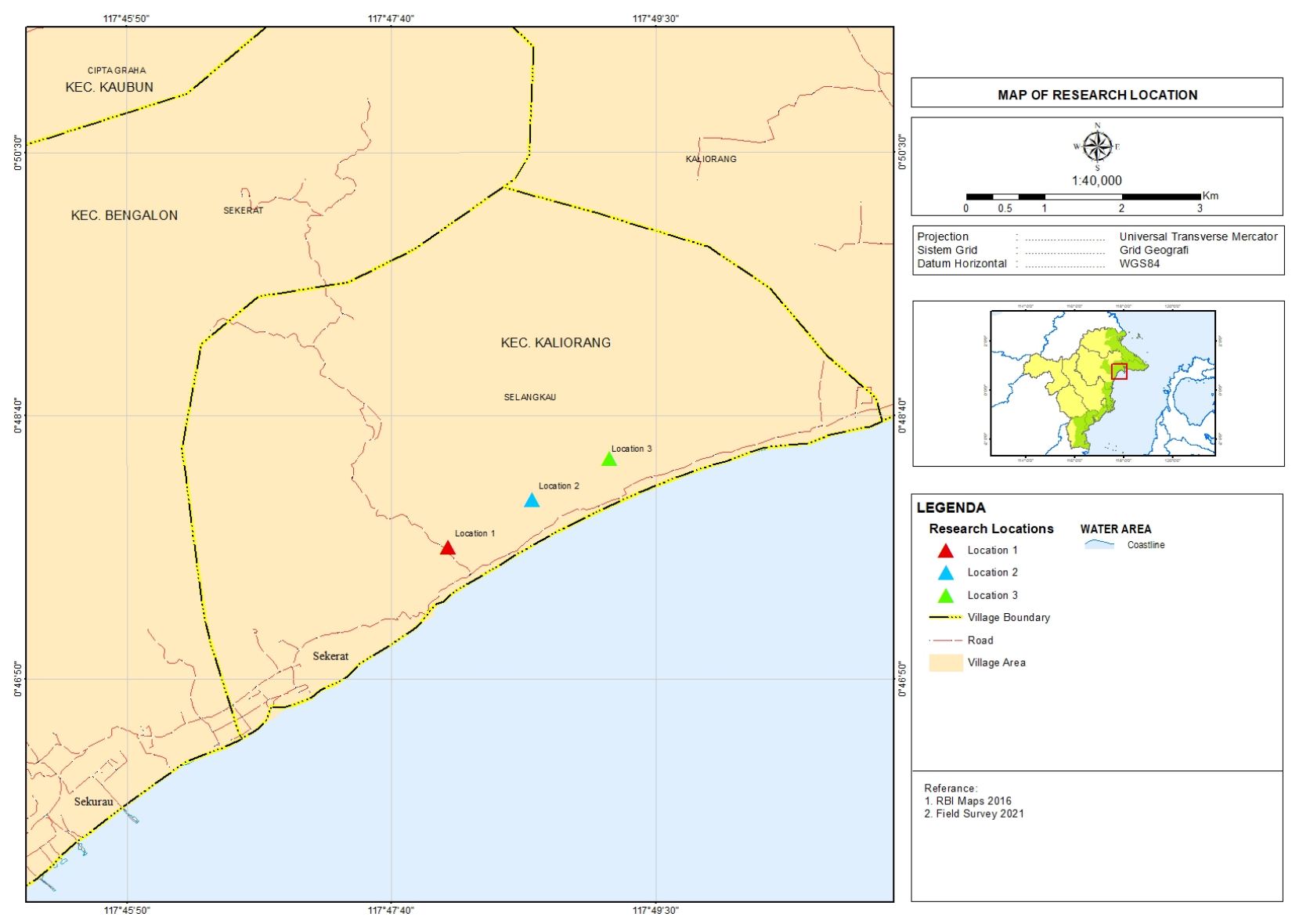

Figure 1. Three locations of sampling in Kaliorang Sub-district, East Kutai District, East Kalimantan Province, Indonesia 

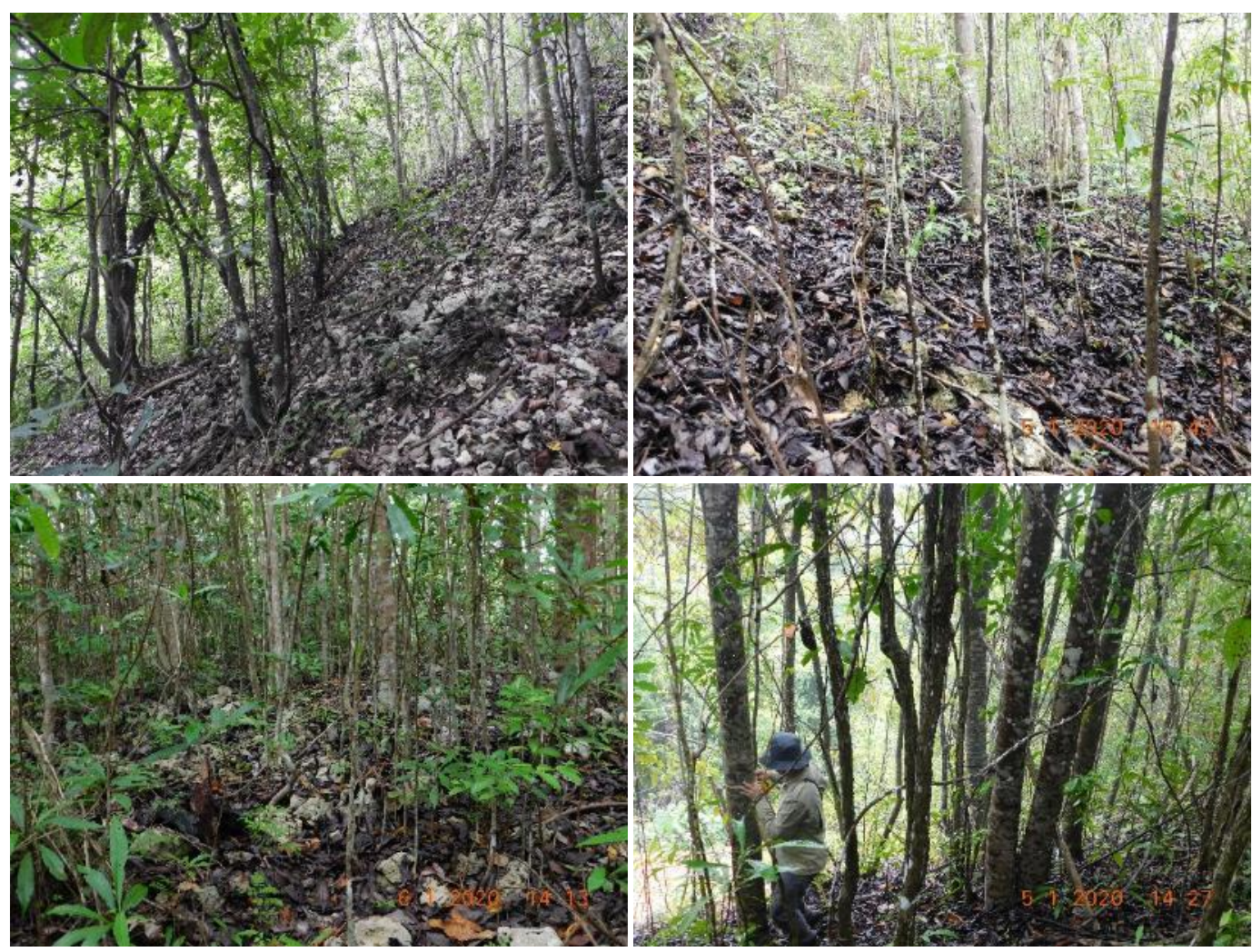

Figure 2. Vegetation coverage in limestone hill forest in which cement factory complex and its supporting facilities will be constructed. This area is densely covered by small sized trees

\section{Vegetation study}

The sampled plots for vegetation study were determined by purposive sampling method using 3 points distributed across the construction site of the new cement factory plan. The vegetation data were collected by combining the transect and multiple plots methods with each point had one transect, and each transect had five plots.

Each plot had the sub-plots to collect data for each growth stage as follows: (a) Seedlings (from sprouts to shoots with less than $1.5 \mathrm{~m}$ tall) and ground vegetation (plants other than tree/woody species such as shrubs, herbs, and lianas) with sub-plot size of $2 \times 2 \mathrm{~m}^{2}$; (b) Saplings (woody plants with a height of more than $1.5 \mathrm{~m}$ and maximum $10 \mathrm{~cm}$ in diameter) with sub-plot size of $5 \times 5 \mathrm{~m}^{2}$; and (c) Poles (woody plants with stem diameter at breast height of 10-20 cm) with sub-plot size of $10 \times 10 \mathrm{~m}^{2}$; (d) Trees (woody plants with stem diameter more than $20 \mathrm{~cm}$ ) with sub-plot size of $20 \times 20 \mathrm{~m}^{2}$. In all plots, the species names (local name and scientific name), and the number of individuals for each species were recorded.

\section{Fauna/wildlife study}

In general, observations on animals were also done in the transects as well as the riverbanks and seaside. The observation methods are described below.

\section{Sign searching}

This method refers to the observation of signs left by animals. The presence of mammal species was identified by the signs left in certain places, such as droppings, footprints, scratch marks, sounds, smells, and nests.

\section{Observation with binoculars}

Observation with binoculars was done along the transects, although the dense jungle condition highly affected the identification work. Normally, a successful observation relies on the sun rays in the edges of the forest or in the area where the trees fall. Observation with binoculars was especially aimed at birds. During this research, observation was done all day from morning to afternoon. The types of observed birds were recorded and identified based on the morphological features, and sounds, if recognized.

\section{Public information}

Information from the local community also provided data on the fauna present in the research location. Ecological data and information for each species were obtained from various literature and previous ecological studies of the species. Considering that there were still many species that might not be identified in the field survey, the collected information and compiled study concerned not only the species observed directly in the field but also the large terrestrial mammal species of which the distribution area might include the research location. In addition, it was also based on the theory of species distribution and habitat similarity. 


\section{Trap camera}

There were relatively hard to find for nocturnal animals through direct observation, so identification was made by installing trap cameras in locations where the animals might be encountered.

\section{Data analysis}

The following analyses were done.

Species Importance Value Index (IVI)

IVI was calculated using the following formula:

$$
\begin{aligned}
& \mathrm{IVI}=\mathrm{RD}+\mathrm{RF}+\mathrm{RDm} \text { (for poles and trees) or } \\
& \text { IVI }=\mathrm{RD}+\mathrm{RF} \text { (for seedlings and saplings) } \\
& \text { with }
\end{aligned}
$$

Density (D) and Relative Density (RD)

$$
\begin{aligned}
& \mathrm{D}=\frac{\text { Eindividual species }}{\text { Size of area sampled }} \\
& \mathrm{RD}=\frac{\text { D ofa species }}{\text { D of all species }} \times 100 \%
\end{aligned}
$$

Frequency (F) and Relative Frequency (RF)

$$
\begin{aligned}
& \mathrm{F}=\frac{\sum \text { Sub-plotofobsenved speciea }}{\sum \text { All sub-plots sanpled }} \\
& \mathrm{RF}=\frac{\text { F of a species }}{\text { F of all species }} \times 100 \%
\end{aligned}
$$

Dominance (Dm) and Relative Dominance (RDm), which was calculated only for the pole and tree stages

$$
\begin{aligned}
& \mathrm{LBD}=1 / 4 \pi \mathrm{d} 2, \mathrm{~d}=\text { stem diameter }(\mathrm{m}) \\
& \mathrm{Dm}=\frac{\text { Size of the plot of a speciea }}{\text { Size of the plot sampled }} \\
& \mathrm{RDm}=\frac{\text { Dm of a species }}{\text { Dm of all species }} \times 100 \%
\end{aligned}
$$

\section{Species Richness Index $(R)$}

The species richness index was calculated using Margalef's formula (Wijana 2014) as below:

$$
\mathrm{R}=\frac{\mathrm{S}-1}{\ln (\mathbb{N})}
$$

Where: $\mathrm{R}$ refers to the species richness index, $\mathrm{S}$ is the number of species, $\mathrm{N}$ is the number of individuals in all species, and ln is the natural logarithm.

\section{Diversity Index (H')}

The diversity index was calculated using a formula by Shannon and Wiener (1949) as stated in Magurran and McGill (2011)

$$
\mathrm{H}^{\mathrm{i}}=-\sum_{\mathrm{i}=1}^{\mathbb{S}}(\mathrm{Pi} \mathrm{x} \ln (\mathrm{Pi}))
$$

Where: $\mathrm{H}^{\prime}$ is the species diversity index, $\mathrm{S}$ is the species forming a community, $\mathrm{Pi}$ is $(\mathrm{ni} / \mathrm{N})$ or the ratio between the number of individuals in a species $\mathrm{i}$ (ni) and the total number of individuals of all species within a community, and ln is the natural logarithm.

\section{Dominance Index $(C)$}

In order to determine whether vegetation community is more dominated by one or several species, the dominance index by Simpson (1949) as described in Magurran and McGill (2011) was used,

$$
\mathrm{C}=\sum_{\mathrm{i}=1}^{\mathrm{S}} \mathrm{Pi}^{2}
$$

Where: $\mathrm{C}$ is Simpson dominance index, $\mathrm{S}$ is the number of species, ni is the total individuals of species $\mathrm{i}, \mathrm{N}$ is the total number of individuals of all species, and $\mathrm{Pi}$ is ni/N as the species proportion of species number-i.

\section{Evenness index}

According to Pielou (1966) in Magurran and McGill (2011), the evenness index (E) was calculated using the following formula,

$$
\mathrm{E}=\frac{\mathrm{H}^{\mathrm{u}}}{\ln (\mathrm{S})}
$$

Where: $\mathrm{E}$ is the species evenness index, $\mathrm{H}^{\prime}$ is the species diversity index, $\mathrm{S}$ is the number of species, and $\mathrm{ln}$ is the natural logarithm.

The species importance value index (IVI), the diversity index $\left(\mathrm{H}^{\prime}\right)$, the species dominance index $(\mathrm{C})$, the species richness index $(\mathrm{R})$, and the species evenness index $(\mathrm{E})$ were classified based on criteria by Fachrul (2007) for the species importance value, as well as by Barbour et al. (1987) for the diversity index, Krebs (1985) for the dominance index, and Magurran and McGill 2011 for the species richness index as described below.

For animal/fauna, successfully identified mammal species were subsequently tabulated based on the family, genus dan species. The list also presented the source of data for each identified species, such as direct observation, droppings, footprints, other signs (nests, tree bark peels, scratch marks, soaking area, and sounds), as well as information from the community.

A list of species was then made both for the plants and wild animals identified along with their conservation status, referring to the existing laws (Indonesia Government 2018), the CITES Appendices for international trade, and the IUCN Red List for the conservation status. Information on the endemism of plants was also collated. 


\section{RESULTS AND DISCUSSION}

\section{Diversity of vegetation community}

The research location, which consists of almost entirely limestone hill forest, is located in Selangkau Village, Kaliorang Sub-district, East Kutai District, East Kalimantan. The vegetation was dominated by small-sized, but dense trees. In general, 29 species were recorded, six included in the IUCN Red List, and one with an Endangered (EN) status, namely Shorea glauca King (Dipterocarpaceae). Buchanania arborescens Blume or the sparrow's mango was found to dominate the vegetation. Further, four species that are endemic (limited distribution) to Kalimantan were also identified (Table 3 ).

The structure of the vegetation community becomes an important parameter in monitoring the ecological condition of an ecosystem (Trodd and Dougill 1998). In addition, species density, dominance and biomass also provide useful insight regarding vegetation community (Mendonca et al. 2017). Table 4 shows that at all growth stages, Buchanania arborescens Blume (Anacardiaceae Family) had the highest importance values with $60.55 \%$ at the seedling stage, $149.19 \%$ at the sapling stage, $197.22 \%$ at the pole stage, and $225.90 \%$ at the tree stage. Based on the criteria stated by Fachrul (2007) in Table 1, B. arborescens has a high importance value. The plant has small fruits, which can serve as feeds for birds in the forest, as well as herbivore mammals. Seeds abundance and diversity has an important influence on the vegetation community structure in a landscape (Shiflett et al. 2010). The abundance of the seeds of $B$. arborescens can be referred from the highest importance value at the seedling stage compared to other species, which indicates the domination of the vegetation community structure in the research area.

The analyses on the richness index $(\mathrm{R})$, the diversity index ( $\left.\mathrm{H}^{\prime}\right)$, evenness index $(\mathrm{E})$ and dominance index $(\mathrm{C})$ of the vegetation in the research location are presented in Table 5 below. Depicted in Table 5, the species richness index $(\mathrm{R})$ at all growth stages are classified as low with an $R$ value were lower than 3.5 based on criteria by Magurran and McGill (2011) stated in Table 1. The biodiversity index $\left(\mathrm{H}^{\prime}\right)$ at seedlings and ground vegetation according to the criteria by Barbour et al. (1987) is moderate with an $\mathrm{H}^{\prime}$ value between 2-3, whereas at other growth stages, it is low with an $\mathrm{H}$ value between 0 and 2 . When a seedling grows into a tree as a result of succession there will be a change of the species composition (Dalmaso et al. 2020). Not all seedlings will grow and become trees, so the diversity index at the tree stage is lower than at the seedling stage.

The dominance index (C) indicates dominating species based on the number of individuals present in the observation plot in which if $\mathrm{C}$ is closer to 0 there are no dominating species, while if $\mathrm{C}$ is closer to 1 , there is a domination of a species (Krebs 1985). From calculations and data analysis, the tree stage had a high level of species dominance with a value of $0.75<\mathrm{C}<1$, while the pole stage had a moderate species dominance level with a value of $0.5<\mathrm{C}<0.75$, and the sapling and seedling/ground vegetation had a relatively low level of species dominance with a value of $0<\mathrm{C}<0.5$.

The evenness index $(\mathrm{E})$ that is higher or closer to 1 means that the number of individual vegetation is evenly distributed in each type, and vice versa. From the results of calculations and data analysis, based on the criteria by Magurran and McGill (2011) in Table 2, it is known that at the growth stages of sapling and seedling/ground vegetation, the vegetation is somewhat evenly distributed with an E value between 0.51-0.75, while at the poles and trees are classified as uneven with an $\mathrm{E}$ value between 0.26 and 0.50 .

Based on the analysis, it was found that the vegetation community at the seedling and sapling stages had the highest species diversity index (H'), species richness index (R), and species evenness index (E) compared to the vegetation community at the pole and tree stages, whereas the dominance index (C) was the lowest. This shows that the vegetation community in the research location had a balanced growth which tends to be stable, based on the vegetation diversity index value of 2.09 at the seedling stage (moderate). The decreased diversity and richness values at the tree stage suggest there might be some disturbances within the vegetation community which might be caused by natural factors, such as competition and predation, or external factors, such as human activities/logging.

Table 2. Classification of Species Evenness Index (E)

\begin{tabular}{lc}
\hline \multicolumn{1}{c}{ Criteria } & Evenness Index (E) \\
\hline Not even & $0.00-0.25$ \\
Less even & $0.26-0.50$ \\
Somewhat even & $0.51-0.75$ \\
Nearly even & $0.76-0.95$ \\
Even & $0.96-1.00$ \\
\hline
\end{tabular}

Note: Magurran and McGill (2011)

Table 1. Classification of the Species Importance Value Index (IVI), Diversity Index (H'), Species Dominance Index (C), and Species Richness Index (R).

\begin{tabular}{lcccc}
\hline Criteria & $\begin{array}{c}\text { IVI } \\
\text { (Fachrul, 2007) }\end{array}$ & $\begin{array}{c}\text { H' } \\
\text { (Barbour et al. 1987) }\end{array}$ & $\begin{array}{c}\text { C } \\
\text { (Krebs, 1985) }\end{array}$ & $\begin{array}{c}\text { R } \\
\text { Magurran and McGill (2011) }\end{array}$ \\
\hline High & $>42.66$ & $>3$ & $0.75<\mathrm{C}<1$ & R $>5.0$ \\
Moderate & $21.96-42.66$ & $2-3$ & $0.5<\mathrm{C}<0.75$ & $3.5-5.0$ \\
Low & $<21.96$ & $0-2$ & $0<\mathrm{C}<0.5$ & $\mathrm{R}<3.5$ \\
\hline
\end{tabular}

Note: For the Species Evenness Index (E), the classification is as follows (Magurran and McGill, 2011) 
Table 3. List of species of recorded in the studied area in Selangkau Village, Kaliorang Sub-district, East Kutai District, East Kalimantan, Indonesia and its conservation status.

\begin{tabular}{|c|c|c|c|c|c|}
\hline Family & Species & IUCN & CITES & UURI & End \\
\hline Anacardiaceae & Buchanania arborescens (Blume) Blume & & & & \\
\hline Annonaceae & Miliusa macropoda Miq. & & & & $\sqrt{ }$ \\
\hline Dipterocarpaceae & Shorea glauca King & $\mathrm{EN}$ & & $\sqrt{ }$ & \\
\hline Euphorbiaceae & Cephalomappa malloticarpa J.J.Sm. & & & & \\
\hline Fabaceae & Fordia brachybotrys Merr. & & & & $\sqrt{ }$ \\
\hline Hypericaceae & Cratoxylum sumatranum (Jack) Blume & $\mathrm{LC}$ & & & \\
\hline Lamiaceae & Vitex pinnata $\mathrm{L}$ & $\mathrm{LC}$ & & & \\
\hline Lygodiaceae & Lygodium circinatum (Burm. f.) Sw. & & & & \\
\hline Malvaceae & Pterospermum diversifolium Blume & & & & \\
\hline Moraceae & Artocarpus lakoocha Roxb. & & & & \\
\hline Myrtaceae & Syzygium grande (Wight) Walp. & & & & \\
\hline Nephrolepidaceae & Nephrolepis biserrata (Sw.) Schott & & & & \\
\hline Pentaphylacaceae & Ternstroemia hosei Ridl. & & & & $\sqrt{ }$ \\
\hline Phyllanthaceae & Cephalomappa malloticarpa J.J.Sm. & & & & \\
\hline Phyllanthaceae & Glochidion lutescens Blume & $\mathrm{LC}$ & & & \\
\hline Picrodendraceae & Austrobuxus nitidus Miq. & & & & \\
\hline Poaceae & Imperata cylindrica (L.) Raeusch. & & & & \\
\hline Primulaceae & Ardisia elliptica Thunb. & & & & \\
\hline Primulaceae & Ardisia pachysandra (Wall.) Mez & & & & \\
\hline Rubiaceae & Psychotria polytricha Miq. & & & & $\sqrt{ }$ \\
\hline Sapindaceae & Guioa diplopetala (Hassk.) Radlk. & & & & \\
\hline Sapindaceae & Paranephelium xestophyllum Miq. & & & & \\
\hline Sapotaceae & Planchonella maingayi (C.B.Clarke) P.Royen & NT & & & \\
\hline Simaroubaceae & Ailanthus triphysa (Dennst.) Alston & & & & \\
\hline Simaroubaceae & Quassia sp. & & & & \\
\hline Symplocaceae & Symplocos cerasifolia Wall. & & & & \\
\hline Thelypteridaceae & Cyclosorus polycarpus Holttum & & & & \\
\hline Violaceae & Rinorea sp. & & & & \\
\hline Vitaceae & Leea indica (Burm. f.) Merr. & $\mathrm{LC}$ & & & \\
\hline
\end{tabular}

A case study in the Philippines, a country with rich biodiversity and a high level of species endemism, found that shifting cultivation has become the primary threat to the rainforest's diversity and structure in the region (Mukul et al. 2020). On the abandoned lands, species density is significantly higher in the oldest site, whereas the diversity index, species evenness, number of stems, size of the basal area and the leaf size index are higher in forests with no disturbance of shifting cultivation (Mukul et al. 2020).

It is important to note that the ecosystem in the research location is the habitat of one protected species based on the Regulation of the Minister of Environment and Forestry of the Republic of Indonesia, namely the Meranti plant (Shorea glauca King) (Indonesia Government 2018). The species is also classified as endangered according to IUCN Red List, as supported by the study finding of the plant's population in which only three individuals were found in the research location at the pole stage and none at other stages. The absence of this Meranti plant at the seedling and sapling stages suggests that the local population of this species is endangered. Therefore, regulations and laws are necessary to protect endangered species and their habitats.
In order to succeed in such a program, incentives may be required for participants (Ward et al. 2018). The impact of the new cement factory development plan in the research location on the existence of Meranti as an endangered species must be considered. Some conservation efforts are needed, for example, by planting the species in the green open space or preserve its habitat outside the factory area through the Corporate Social Responsibility (CSR) scheme by involving the participation of the local community.

The forest vegetation also provided food resources for the local community. In various regions, wild plants consumption has become a long-standing tradition, involving a great range of plant families. Some plants must be cooked, while others are safe to consume raw. The parts of plants which can be consumed are fruits, tubers, leaves, and stems. Therefore, the high diversity of wild plants can serve as a food source all year long (Ojelel et al. 2019). Local wisdom or indigenous knowledge practices from the local community continually offers support for the conservation of biodiversity with the cultural landscape that it forms (Aziz et al. 2018). 
Table 4. Species importance value index (IVI) at seedling, sapling, pole and tree stages in the studied area in Selangkau Village, Kaliorang Sub-district, East Kutai District, East Kalimantan.

\begin{tabular}{|c|c|c|c|c|c|c|}
\hline Family & Species & Indonesian name & $\begin{array}{l}\text { IVI } \\
\text { Seedling }\end{array}$ & $\begin{array}{l}\text { IVI } \\
\text { Sapling }\end{array}$ & $\begin{array}{l}\text { IVI } \\
\text { Pole }\end{array}$ & IVI Tree \\
\hline Anacardiaceae & Buchanania arborescens (Blume) & $\begin{array}{l}\text { Mangga burung pipit, rawa- } \\
\text { rawa pipit }\end{array}$ & 60.55 & 149.19 & 197.22 & 225.90 \\
\hline Sapindaceae & Guioa diplopetala (Hassk.) Radlk. & Pohon aras & 25.87 & 5.45 & - & - \\
\hline Hypericaceae & Cratoxylum sumatranum (Jack) Blume & $\begin{array}{l}\text { Irat, geranggang, manding, } \\
\text { mentialing, serungan, } \\
\text { serungan mampat }\end{array}$ & 15.45 & 26.89 & 11.06 & 8.74 \\
\hline Myrtaceae & Syzygium grande (Wight) Walp. & Apel laut & 14.52 & 18.72 & 5.50 & 21.84 \\
\hline Phyllanthaceae & Glochidion lutescens Blume & $\begin{array}{l}\text { Mareme, manyam, obah nasi } \\
\text { timbau, timbau }\end{array}$ & 14.27 & 49.15 & 27.66 & 8.67 \\
\hline Simaroubaceae & Ailanthus triphysa (Dennst.) Alston & - & 10.15 & - & 3.17 & 8.22 \\
\hline Fabaceae & Fordia brachybotrys Merr. & - & 9.20 & 5.58 & - & - \\
\hline Euphorbiaceae & Cephalomappa malloticarpa J.J.Sm. & - & 7.72 & 5.34 & - & - \\
\hline Vitaceae & Leea indica (Burm. f.) Merr. & Ki tuwa, girang merah & 6.53 & 6.85 & - & - \\
\hline Poaceae & Imperata cylindrica (L.) Raeusch. & Ilalang, alang-alang & 6.28 & - & - & - \\
\hline Lygodiaceae & Lygodium circinatum (Burm. f.) Sw. & Paku hata & 6.03 & - & - & - \\
\hline Nephrolepidaceae & Nephrolepis biserrata (Sw.) Schott & Paku harupat & 5.32 & - & - & - \\
\hline Sapindaceae & Paranephelium xestophyllum Miq. & - & 3.38 & 2.36 & 5.75 & 9.25 \\
\hline Symplocaceae & Symplocos cerasifolia Wall. & - & 3.38 & - & 2.66 & 8.45 \\
\hline Thelypteridaceae & Cyclosorus polycarpus Holttum & Tumbuhan paku & 3.14 & - & - & - \\
\hline Picrodendraceae & Austrobuxus nitidus Miq. & - & 2.18 & 3.38 & - & - \\
\hline Malvaceae & Pterospermum diversifolium Blume & $\begin{array}{l}\text { Bayur jantan, cerlang, } \\
\text { balangkoras, balang }\end{array}$ & 1.69 & 4.23 & 3.45 & - \\
\hline Rubiaceae & Psychotria polytricha Miq. & - & 1.45 & - & - & - \\
\hline Simaroubaceae & Quassia sp. & Kayu pahit & 1.45 & - & - & - \\
\hline Pentaphylacaceae & Ternstroemia hosei Ridl. & Buwa dawat/papar bubu & 1.45 & - & - & - \\
\hline Annonaceae & Miliusa macropoda Miq. & - & - & 9.12 & - & - \\
\hline Primulaceae & Ardisia elliptica Thunb. & Lempeni & - & 4.17 & - & - \\
\hline Lamiacea & Vitex pinnata $\mathrm{L}$. & $\begin{array}{l}\text { Laban, leban, amola, agil, } \\
\text { humulawan, kalapapa, } \\
\text { kulimpapa batu, kulimpapa }\end{array}$ & - & 4.18 & 10.18 & - \\
\hline Sapotaceae & $\begin{array}{l}\text { Planchonella maingayi (C.B. Clarke) } \\
\text { P.Royen }\end{array}$ & - & - & 2.59 & - & - \\
\hline Primulaceae & Ardisia pachysandra (Wall.) Mez & - & - & 2.79 & - & - \\
\hline Violaceae & Rinorea sp & Kokosan monyet & - & - & 18.16 & - \\
\hline Phyllanthaceae & Chephalomoppa malloticarpa J.J.Sm. & - & - & - & 6.22 & - \\
\hline Dipterocarpaceae & Shorea glauca King & Meranti, tengkawang & - & - & 5.87 & - \\
\hline Moraceae & $\begin{array}{l}\text { Artocarpus lakoocha Roxb. } \\
\text { Total }\end{array}$ & Buah monyet & - & - & $\begin{array}{l}3.11 \\
300\end{array}$ & $\begin{array}{l}8.93 \\
300\end{array}$ \\
\hline
\end{tabular}

Table 5. The analyses on Richness Index (R), Diversity Index $\left(H^{\prime}\right)$, Evenness Index (E) and Dominance Index (C) of the vegetation in the research location.

\begin{tabular}{lcccc}
\hline $\begin{array}{l}\text { Diversity } \\
\text { Index }\end{array}$ & Seedling & Sapling & Pole & Tree \\
\hline R & 3.16 & 2.56 & 2.18 & 1.68 \\
H' & 2.09 & 1.43 & 0.83 & 0.71 \\
C & 0.22 & 0.40 & 0.69 & 0.72 \\
E & 0.70 & 0.51 & 0.32 & 0.34 \\
\hline
\end{tabular}

The local wisdom practice of the traditional community has effectively managed the forest ecosystem through the zonation system, in which the areas are divided into zones for food and remedies, hunting zone, land cultivation and residence, bird habitat, taboo, and the river area. This is a form of biodiversity conservation practice that maintains local tradition (Tamalene and Almudhar 2017).

\section{Diversity of wildlife}

According to direct observation on the field, as well as the information from company workers and the local community, a list of species of fauna is presented in Table 6. Some of them are protected animals based on the Regulation of the Minister of Environment and Forestry of the Republic of Indonesia (Indonesia Government 2018), IUCN Red List and CITES. From the result of the fauna study in the research location, there were 67 animal species consisting of 42 species of birds, 14 mammals, and 11 amphibians and reptiles. Of 67 recorded species, 12 are protected by the Indonesian Government laws, 63 are included in the IUCN Red List, and 10 species are regulated in CITES. 
Table 6. Species of fauna in the research location Selangkau Village, Kaliorang Sub-district, East Kutai District, East Kalimantan, Indonesia

\begin{tabular}{|c|c|c|c|c|}
\hline Family & Species & Indonesian name & Conservation status & Note \\
\hline \multicolumn{5}{|l|}{ Aves } \\
\hline Accipitridae & Elanus caeruleus & Elang tikus & $\mathrm{D}, \mathrm{LC}, \mathrm{II}$ & Interview \\
\hline Accipitridae & Haliastur indus & Elang bondol & $\mathrm{D}, \mathrm{LC}, \mathrm{II}$ & Interview \\
\hline Accipitridae & Pernis ptilorhynchus & Sikep madu asia & $\mathrm{D}, \mathrm{LC}, \mathrm{II}$ & Observation \\
\hline Alcedinidae & Ceyx erithaca & Udang api & $\mathrm{D}, \mathrm{LC}$ & Observation \\
\hline Alcedinidae & Pelargopsis capensis & Pekaka emas & $\mathrm{D}, \mathrm{LC}$ & Observation \\
\hline Artamidae & Artamus leucorynchus & Kekep babi & $\mathrm{LC}$ & Observation \\
\hline Ardeidae & Egretta sacra & Kuntul karang & $\mathrm{LC}$ & Observation \\
\hline Bucerotidae & Buceros rhinoceros & Rangkong badak & $\mathrm{D}, \mathrm{NT}, \mathrm{II}$ & Interview \\
\hline Chloropseidae & Chloropsis sonnerati & Cica daun kecil besar & $\mathrm{LC}$ & Observation \\
\hline Columbidae & Streptopelia chinensis & Tekukur biasa & $\mathrm{LC}$ & Observation \\
\hline Columbidae & Treron capellei & Punai besar & VU & Observation \\
\hline Columbidae & Delimukan zamrud & Punai tanah & $\mathrm{LC}$ & Observation \\
\hline Corvidae & Corvus enca & Gagak hutan & $\mathrm{LC}$ & Observation \\
\hline Corvidae & Corvus macrorhynchos & Gagak kampung & $\mathrm{LC}$ & Observation \\
\hline Cuculidae & Centropus bengalensis & Bubut Alang-alang & $\mathrm{LC}$ & Observation \\
\hline Cuculidae & Centropus sinensis & Bubut Besar & $\mathrm{LC}$ & Observation \\
\hline Dicruridae & Dicrurus paradiseus & Srigunting batu & $\mathrm{LC}$ & Observation \\
\hline Estrildidae & Lonchura fuscans & Bondol Kalimantan & $\mathrm{LC}$ & Observation \\
\hline Eurylaimidae & Eurylaimus ochromalus & Sempur hujan darat & NT & Observation \\
\hline Hemiprocnidae & Hemiprocne comata & Tepekong rangkang & $\mathrm{LC}$ & Observation \\
\hline Megalaimidae & Caloramphus fuliginosus & Takur ampis & $\mathrm{LC}$ & Observation \\
\hline Megalaimidae & Megalaima mystacrophanus & Takur warna-warni & NT & Observation \\
\hline Meropidae & Merops viridus & Kirik-kirik biru & $\mathrm{LC}$ & Observation \\
\hline Motacillidae & Anthus novaeseelandiae & Apung tanah & $\mathrm{LC}$ & Observation \\
\hline Nectariniidae & Anthreptes malacensis & Burungmadu kelapa & $\mathrm{D}, \mathrm{LC}$ & Observation \\
\hline Passeridae & Passer montanus & Burung gereja erasia & $\mathrm{LC}$ & Observation \\
\hline Phasianidae & Lophura bulweri & Sempidan biru & VU & Interview \\
\hline Picidae & Picoides moluccensis & Caladi tilik & $\mathrm{LC}$ & Observation \\
\hline Picidae & Dinopium javanense & Pelatuk besi & $\mathrm{LC}$ & Observation \\
\hline Pycnonotidae & Amphoixus phaeocephalus & Empuloh Irang & $\mathrm{LC}$ & Observation \\
\hline Pycnonotidae & Pycnonotus aurigaster & Cucak kutilang & $\mathrm{LC}$ & Observation \\
\hline Pycnonotidae & Pycnonotus goiavier & Merebah cerukcuk & $\mathrm{LC}$ & Observation \\
\hline Pynonotidae & Pynonotus erythropthalmus & Merbah kacamata & $\mathrm{LC}$ & Observation \\
\hline Rallidae & Amaurornis phoenicurus & Kareo padi & $\mathrm{LC}$ & Observation \\
\hline Rhipuduridae & Rhipudura javanica & Kipasan belang & $\mathrm{LC}$ & Observation \\
\hline Sturnidae & Acridotheres cristatellus & Kerak jambul & $\mathrm{LC}$ & Observation \\
\hline Sturnidae & Acridotheres javanicus & Kerak kerbau & $\mathrm{LC}$ & Observation \\
\hline Sturnidae & Aplonis panayensis & Perling kumbang & $\mathrm{LC}$ & Observation \\
\hline Sturnidae & Gracula religiosa & Tiong emas & $\mathrm{D}, \mathrm{LC}, \mathrm{II}$ & Observation \\
\hline Sylviidae & Orthotomus ruficeps & Cinenen kelabu & $\mathrm{LC}$ & Observation \\
\hline Timaliidae & Stachyris maculata & Tapus tungir merah & NT & Observation \\
\hline Vangidae & Hemipus hirundinaceus & Jing-jing batu & $\mathrm{LC}$ & Observation \\
\hline \multicolumn{5}{|l|}{ Mammals } \\
\hline Cercopithecidae & Macaca fascicularis & Monyet ekor panjang & $\mathrm{LC}$ & Observation \\
\hline Cercopithecidae & Macaca nemestrina & Monyet beruk & $\mathrm{VU}$ & Observation \\
\hline Cercophitecidae & Trachypithecus cristatus & Lutung kelabu & $\mathrm{D}, \mathrm{NT}$ & Observation \\
\hline Cervidae & Muntiacus muntjak & Kijang muncak & $\mathrm{LC}$ & Interview \\
\hline Cervidae & Rusa unicolor & Rusa sambar & VU & Interview \\
\hline Felidae & Felis bengalensis & Kucing kuwuk & $\mathrm{D}, \mathrm{II}$ & Interview \\
\hline Hystricidae & Hystrix brachyura & Landak raya & $\mathrm{D}, \mathrm{LC}, \mathrm{I}$ & Interview \\
\hline Sciuridae & Callosciurus notatus & Bajing kelapa & $\mathrm{LC}$ & Observation \\
\hline Suidae & Sus barbatus & $B a b i$ & VU & Interview \\
\hline Tragulidae & Tragulus kanchil & Pelanduk kancil & $\mathrm{LC}$ & Interview \\
\hline Tupaiidae & Tupaia tana & Tupai tanah & $\mathrm{LC}$ & Interview \\
\hline Ursidae & Helarctos malayanus & Beruang madu & $\mathrm{D}, \mathrm{VU}, \mathrm{I}$ & Interview \\
\hline Viverridae & Viverra tangalunga & Musang Tenggalung & $\mathrm{LC}$ & Interview \\
\hline Viverridae & Cynogale bennettii & Musang air & $\mathrm{D}, \mathrm{EN}$ & Observation \\
\hline
\end{tabular}




Amphibians and reptiles
Ranidae
Ranidae
Rhacophoridae
Agamidae
Agamidae
Agamidae
Colubridae
Elapidae
Pythonidae
Scincidae
Varanidae

Amnirana nicobariensis
Hylarana erythraea
Polypedates leucomystax
Bronchocela cristatella
Bronchocela jubata
Draco volans
Dendrelaphis pictus
Ophiophagus hannah
Python reticulatus
Eutropis multifasciata
Varanus salvator

Kongkang jangkrik
Kongkang gading
Katak pohon bergaris
Bunglon jambul hijau
Bunglon surai
Kadal terbang
Ular tambang
Ular kobra
Ular sanca
Kadal
Biawak

$\begin{array}{ll}\text { LC } & \text { Observation } \\ \text { LC } & \text { Observation } \\ \text { LC } & \text { Observation } \\ \text { LC } & \text { Observation } \\ \text { LC } & \text { Observation } \\ \text { LC } & \text { Observation } \\ & \text { Observation } \\ \text { VU, II } & \text { Interview } \\ \text { II } & \text { Interview } \\ \text { LC } & \text { Observation } \\ \text { LC, II } & \text { Observation }\end{array}$

Note: D: Protected by Regulation of the Minister of Environment and Forestry of the Republic of Indonesia Number P.106/MENLHK/SETJEN/KUM.1/12/2018. LC/LR: Least Concern/Lower Risk. NT: Near Threatened. VU: Vulrenable. EN: Endangered. I, II: Apendix I or II CITES

Habitat types in a forest in Ketapang, West Kalimantan found eight species of diurnal mammals across six families (Putra et al. 2020), although the amphibians have a lower number. Another case study in the conservation forest of Gunung Semahung in the Landak District of West Kalimantan identified 18 species from 6 families with a total number of 357 individuals (Yani et al. 2015).

According to Table 6, the biodiversity in the research location can be classified as good, with 42 bird species, 7 of which are protected. The distinctive characteristics of birds make them a natural indicator of the biodiversity richness of a region. In other words, the diversity of birds represents a high level of wildlife biodiversity because birds have a niche or diverse habitats, and their communities are affected by the vegetation community structure in the forest (McNeely et al.1990; Hino 2000).

Because the existence of the 42 bird species is affected by the vegetation community structure in the research location, the plan to develop a construction in the area will change the vegetation community structure, which will further affect the diversity and population of birds in the area. Change in the vegetation structure caused by longterm logging can significantly decrease the population and richness of the bird species that rely heavily on the forest (Sekercioglu 2002; Ocampo-Peñuela 2020). Therefore, bird conservation must maintain the structure and diversity of vegetation in the forest.

In addition, there is also a range of protected mammals classified as endangered species, such as sun bears, otter civets, leopard cats, and silvery lutung. This shows that the research area had important types of animals. For this reason, in response to the plan to develop a new cement factory in the research location, conservation efforts are crucial to be done; for example, by transferring the animals into a new habitat that resembles the original one. The efforts are important as the threatened animals will instinctively attempt to seek a new habitat to continue their regeneration (Kloskowski and Frączek 2017). The habitat transfer may be done by setting up a corridor that connects the old habitat and the new one to guide the animals (Aars and Ims 1999).
Threats toward the wildlife habitat in the research location are begun at the first stage of the new factory construction preparation where the land will be cleared and the topsoil layer will be removed. Naturally, this involves removing all the vegetation in the topsoil. This removal will eventually lead to negative impacts on the vegetation and wildlife diversity which rely on the land as their habitats. The loss of pristine and undisturbed forest and habitat fragmentation may result in loss of species diversity, mainly vertebrates (Ocampo-Peñuela 2020). The expansion of mining activities, especially in the mountain area $(>750 \mathrm{~m})$ also becomes a severe threat toward biodiversity sustainability. Much of the area is the habitat for endangered species. Therefore, a management plan is necessary and must involve in situ and ex situ conservation to reduce the potential threat of mining activities in the future (Droissart et al. 2019; Pratiwi et al. 2021).

Environment management can also be done with a technological approach, as follows: (1) logging can only be done on the specific area where the factory and its supporting facilities will be built, and letting the plants/trees outside the area remain as a green belt or a green open space; and (2) making a green open space with plants with multiple functions for the aesthetics, conservation, as well as habitat for the wildlife. The types of plants to be selected should include the local species with a high importance value in the ecosystem such as sparrow's mango (Buchanania arborescens), meranti (Shorea glauca), or non-invasive non-local plants which are suitable for the land such as teak (Tectona grandis), weeping fig (Ficus benjamina), Japanese bamboo (Pseudosasa japonica) and kersen/kerukup siam/talok (Muntingia calabura) trees.

Likewise, after the mining activities are completed and the factory operations stop, land reclamation and revegetation can be carried out with local plants that are easy to grow and adapt with the land condition in the former mining area (Anderson et al. 2016). Reforestation should be considered to repair the loss of habitat that might happen during the mining process. Trees to be planted should be chosen not only based on the historical past of the land but also related to the quality of the soil, ecological 
function of species and also closely related phylogenetic groups of former species that grow in cleared areas (Chechina and Hamman 2015; Gastauer et al. 2018; Pietrzykowski 2019) Vegetation density and diversity become important factors which determine the density and diversity of birds. Therefore, revegetation primarily works with species that can invite wild animals, e.g., trees with seeds that feed birds, or flower plants that offer nectars for insects and nectar-eating birds.

The reclamation of ex-mining land can improve carbon stocks in the soil and plant biomass in the form of forests to benefit the surrounding community (Hirons et al. 2013). Further, there are a set of criteria and indicators in the success of sustainable forest management. Five principles that can be used as a reference in the forest biodiversity conservation are (1) the maintenance of connectivity; (2) the maintenance of landscape heterogeneity; (3) the maintenance of stand structural complexity; (4) the maintenance of aquatic ecosystem integrity; and (5) the use of natural disturbance regimes to guide human disturbance regimes (Lindenmayer et al. 2006). The substrate difference and types of disturbance affect the recovery of the endangered plant species population. The plant habitat interrupted by humans may be recovered as long as there is a natural ecosystem process, as well as the vegetation community structure and the habitat heterogeneity (Robinson and Hermanutz 2015).

Based on the above elaboration, it can be concluded that the vegetation community structure in the forest ecosystem of Selangkau Village, Kaliorang Sub-district, East Kutai District, East Kalimantan Province was quite diverse and tends to be stable, based on the diversity index value. B. arborescens (Blume) had the highest importance value at all growth stages. One protected species was identified, namely Shorea glauca King (Meranti), meaning it is imperative to make management efforts toward the impacts of the new cement factory development plan in the future on this plant. One of the efforts can be made by growing the plant species in the green open space area or by preserving its habitat outside the factory area through the Corporate Social Responsibility (CSR) scheme. On the other hand, the study findings on fauna show that many protected species are identified based on the regulations and laws with endangered status. Therefore, conservation efforts of the protected species must be made regarding the new cement factory in the research location, namely by transferring the species into a new habitat that resembles the original one. Moreover, it is also imperative to have a green open space that can serve as the new habitat for the protected species.

\section{ACKNOWLEDGEMENTS}

We would like to thank the management of PT. Kobexindo Cement for funding the flora and fauna study in the research location. We also thank the management of the company for giving the permission to publish the study findings.

\section{REFERENCES}

Aars J, Ims RA. 1999. The effect of habitat corridors on rates of transfer and interbreeding between vole demes. Ecology 80 (5): 1648-1655. DOI: 10.1890/0012-9658(1999)080[1648:TEOHCO]2.0.CO;2

Anderson BW, Ohmart RD, Rice J. 2016. Avian and vegetation community structure and their seasonal relationships in the lower Colorado River Valley. Cooper Ornithol Soc 85 (4): 392-405. DOI: $10.2307 / 1367978$

Aziz IR, Rahajeng ARP, Susilo. 2018. The role of ethnobotany in conservation by several tribes in Indonesia. Proceeding of National Seminar of Indonesian Megabiodiversity (April) [Indonesian]

Barbour GM Burk JK, Pitts WD. 1987. Terrestrial Plant Ecology. The Benyamin/Cummings Publishing Company Inc, Los Angeles.

Bodegom S, Pelser PB, Kessler PJA. 1999. Seedlings of Secondary Forest Tree Species of East Kalimantan, Indonesia. MOFEC-TropenbosKalimantan Project.

Budiharta S, Meijaard E (in press) State of Kalimantan's Biodiversity. In: Resosudarmo BP, Imansyah MH, Napitupulu L (eds) Development, Environment and the People of Kalimantan. Indonesian Regional Science Association (IRSA), Jakarta, Indonesia. [Indonesian]

Chechina M, Hamann A. 2015. Choosing species for reforestation in diverse forest communities: social preference versus ecological suitability. Ecosphere 6 (11): 1-13. DOI: 10.1890/ES15-00131.1

Dalmaso CA, Marques,MCM, Higuchi P, Zwiener VP, Marques R. 2020. Spatial and temporal structure of diversity and demographic dynamics along a successional gradient of tropical forests in southern Brazil. Ecol Evol 10 (7): 3164-3177. DOI: 10.1002/ece3.5816

Droissart V, Lachenaud O, Dauby G, Dessein S, Kamdem G, Nguembou KC, Simo-Droissart M, Stévart T, Taedoumg H, Sonké, B. 2019. Mine versus wild: A plant conservation checklist of the rich iron-ore ngovayang massif area (South Cameroon). Plant Ecol Evol 152 (1): 829. DOI: $10.5091 /$ plecevo.2019.1547

Fachrul MF. 2007.Ecological Sampling Method $1^{\text {st }}$ Ed. Penerbit Bumi Aksara, Jakarta. [Indonesian]

Falah F, Sayektiningsih T, Noorcahyati N. 2013. (Diversity and utilization of medicinal plants by local community around Gunung Beratus Protection Forest, East Kalimantan). J For Conserv Res 10 (1): 1-18. DOI: 10.20886/jphka.2013.10.1.1-18 [Indonesian]

Fiqa AP, Fauziah F, Lestari DA, Budiharta S. 2019. The importance of insitu conservation area in mining concession in preserving diversity, threatened and potential floras in East Kalimantan, Indonesia. Biodiversitas J Biol Divers 20: 198-210. DOI: 10.13057/biodiv/d200123

Gastauer M, Silva JR, Junior CFC, Ramos SJ, Filho PWS, Neto AEF, Siqueira J. 2018. Mine land rehabilitation: Modern ecological approaches for more sustainable mining. J Cleaner Prod 172: 14091422. DOI: $10.1016 /$ j.jclepro.2017.10.223

Harrison, ME, Ottay, JB, D'Arcy, LJ, et al. 2020. Tropical forest and peatland conservation in Indonesia: Challenges and directions. People Nat 2: 4-28. DOI: $10.1002 /$ pan3.10060

Hino T. 2000. Bird community and vegetation structure in a forest with a high density of Sika deer. Japanese J Ornithol 48: 197-204. DOI: 10.3838/jjo.48.197

Hirons M, Hilson G, Asase A, Hodson ME. 2013. Mining in a changing climate: What scope for forestry-based legacies?. J Clean Prod 8 (1): 430-438. DOI: 10.1016/j.jclepro.2013.11.025

Hou H, Ding Z, Zhang S, Guo S, Yang Y, Chen Z, Wang X. 2021. Spatial estimate of ecological and environmental damage in an underground coal mining area on the Loess Plateau: Implications for planning restoration interventions. J Cleaner Prod 287 (10): 125061. DOI: 10.1016/j.jclepro.2020.125061

Indonesia Government. 2018. Republic of Indonesia's Environment and Forestry Ministeries Regulation No. P.106/MENLHK/SETJEN/KUM.1/12/2018 regarding Secondary changes of Environment and Forestry Ministeries Regulation No. P.20/Menlhk/Setjen/Kum.1/6/2018 regarding Protected Plants and Animal Species. [Indonesian]

Ismawan A, Rahayu SE, Dharmawan A. 2015. Birds Diversity and Abundance in Prevab of Kutai National Park, East Kalimantan. Jurnal-Online UM. [Indonesian]

Kessler PJA, Sidiyasa K, Kartawinata JA 1999. Trees of the Balikpapan, Samarinda Area, East Kalimantan, Indonesia: a manual to 280 selected species.. MOFEC-Tropenbos-Kalimantan Project, Balikpapan, Indonesia. 
Kessler PJA. 2000. Secondary Forest Trees of Kalimantan, Indonesia-A Manual to 300 Selected Species. MOFEC-Tropenbos-Kalimantan Project, Balikpapan, Indonesia

Kloskowski J, Frączek K. 2017. A novel strategy to escape a poor habitat red-necked grebes transfer flightless young to other ponds. Acta Etho 20 (2): 191-195. DOI: 10.1007/s 10211-017-0254-7

Krebs CJ. 1985. Ecology: Experimental Analysis of Distribution and Abundance. Harper and Row Publisher, Philadelphia.

Lindenmayer DB, Franklin JF, Fischer J. 2006. General management principles and a checklist of strategies to guide forest biodiversity conservation. Biol Conserv 131 (3): 433-445. DOI: 10.1016/j.biocon.2006.02.019

MacKinnon K, Hatta G, Halim H, Mangalik, A. 2000. Ecology of Kalimantan Book III. Prenhallindo, Jakarta. [Indonesian]

Magurran AE, McGill BJ. 2011. Biological diversityfrontiers in measurement and assessment. XVII +345 pp. Oxford University Press, Oxford.

McNeely JA, Miller KR, Reid WV, Mittermeier RA, Werner TB. 1990. Conserving the world's biological diversity. International Union for Conservation of Nature and Natural Resources, Switzerland.

De Mendonca BAF, Filho EIF, Schaefer CEGR, De Mendonca JF, Vasconcelos BNF. 2017. Soil-vegetation relationships and community structure in a " terra-firme "-white-sand vegetation gradient in Viruá National Park, northern Amazon, Brazil. Anais Acad Bras Ciencias 89 (2): 1269-1293. DOI: 10.1590/0001-3765201720160666

Lestari DA, Fiqa AP, Fauziah, Budiharta S. 2019. Growth evaluation of native tree species planted on post coal mining reclamation site in East Kalimantan, Indonesia. Biodiversitas 20: 134-143. DOI: 10.13057/biodiv/d200116

Mukul SA, Herbohn J, Firn J. 2020. Rapid recovery of tropical forest diversity and structure after shifting cultivation in the Philippines uplands. Ecol Evol 10 (14): 7189-7211. DOI: 10.1002/ece3.6419

Myroniuk V, Bilous A, Khan Y, Terentiev A, Kravets P, Kovalevskyi S, See L. 2020. Tracking rates of forest disturbance and associated carbon loss in areas of illegal amber mining in Ukraine using landsat time series. Remote Sens 12 (14): 2235. DOI: 10.3390/rs 12142235

Ngatiman, Budiono M. 2009. Weeds Diversity in Dipterocarps Forest of East Kalimantan. Balai Besar Penelitian Dipterocarpa, Samarinda [Indonesian]

Ocampo-Peñuela N, Garcia-Ulloa J, Kornecki I, Philipson CD, Ghazoul J. 2020. Impacts of four decades of forest loss on vertebrate functional habitat on Borneo. Front For Glob Change 3: 53. DOI: 10.3389/ffgc. 2020.00053

Ojelel S, Mucunguzi P, Katuura E, Kakudidi EK, Namaganda M, Kalema J. 2019. Wild edible plants used by communities in and around selected forest reserves of Teso-Karamoja region, Uganda. J Ethnobiol Ethnomed 15 (1): 1-14. DOI: 10.1186/s13002-018-0278-8

Pietrzykowski M. 2019. Tree species selection and reaction to mine soil reconstructed at reforested post-mine sites: Central and eastern European experiences. Ecol Eng 3: 100012. DOI 10.1016/j.ecoena.2019.100012

Potapov P, Hansen MC, Laestadius L, Turubanova S, Yaroshenko A, Thies C, Esipova E. 2017. The last frontiers of wilderness: Tracking loss of intact forest landscapes from 2000 to 2013. Sci Advan 3: e1600821 DOI: $10.1126 /$ sciadv. 1600821

Pratiwi, Narendra BH, Siregar CA, Turjaman M, Hidayat A, Rachmat HH, Mulyanto B, Suwardi, Iskandar, Maharani R, et al. Managing and reforesting degraded post-mining landscape in Indonesia: A Review. Land 10: 658. DOI: 10.3390/land10060658

PT Cobexindo Cement. 2020. Environmental Impact Assessment Report of PT Kobexindo Cement (Environmental Impact Analysis of Construction Planning and Operation of Cement Manufacture and its Supporting Facilities with Production Capacity of 8.000.000 tonnes/ year in the 174 hectare Area by PT. Kobexindo Cement. DLH Kutai Timur, Kutai Timur, Indonesia [Indonesian]

Purwandani JA, Michaud G. 2021. What are the drivers and barriers for green business practice adoption for SMEs? Environ Syst Decisions 1-7. DOI: $10.1007 / \mathrm{s} 10669-021-09821-3$

Putra RM, Erianto E. Dewantara I. 2020.Mammalian Diversity in Several Types of Forest in IUPHHK PT HUTAN Ketapang Industri Forest Area, Ketapang District. Jurnal Hutan Lestari 7 (4): 1695-1701. DOI: 10.26418/jhl.v7i4.38607 [Indonesian]

Robinson J, Hermanutz L. 2015. Evaluating human-disturbed habitats for recovery planning of endangered plants. J Environ Manag 150: 157163. DOI: $10.1016 /$ j.jenvman.2014.10.033

Sekercioglu CH. 2002. Effects of forestry practices on vegetation structure and bird community of Kibale National Park, Uganda. Biol Conserv 107 (2): 229-240. DOI: 10.1016/S0006-3207(02)00097-6

Shiflett SA, Young DR, Young DR. 2010. Avian seed dispersal on Virginia Barrier Islands : potential influence on vegetation community structure and patch dynamics. Am Midland Nat 164 (1): 91-106. DOI: DOI: $10.1674 / 0003-0031-164.1 .91$

Sidiyasa K. 2015. Endemic Tree Species of Kalimantan. Balai penelitian Dipterocarpaceae Teknologi Konservasi Sumber Daya Alam. Samboja. [Indonesian]

Tamalene MN, Almudhar MHI. 2017. Local knowledge of management system of forest ecosystem by Togutil Ethnic group on Halmahera Island, Indonesia: Traditional utilization and conservation. Int J Conserv Sci 8 (3): 497-508.

Tripathi SK, Roy A, Kushwaha D, Lalnunmawia F, Lalnundanga, Lalraminghlova H, Lalnunzira C. 2016. Perspectives of forest biodiversity conservation in Northeast India. J Biodivers Bioprospecting Dev 03 (2): 1-9. DOI: 10.4172/2376-0214.1000157

Trodd NM, Dougill AJ. 1998. Monitoring vegetation dynamics in semiarid African rangelands. Appl Geogr 18 (4) 315-330.

Ward LK, Green GT, Izlar RL. 2018. Family forest landowners and the endangered species act: assessing potential incentive programs. J For 116 (6): 529-538. DOI: 10.1093/jofore/fvy048

Wijana N. 2014. Methods of Vegetation Analysis. Penerbit Plantaxia, Yogyakarta. [Indonesian]

Yani A, Said S, Erianto. 2015. Diversity of Anurans in protected forest of Gunung Semahung, Sengah Temila Sub-district, Landak District, West Kalimantan. Jurnal Hutan Lestari 3 (1): 15-20. DOI: 10.26418/jhl.v3i1.8877 [Indonesian]

Yusriyah K, Fatoni A, Mansyur MA. 2020. Communication networks analysis on information dissemination of the moving of capital city from Jakarta to East Kalimantan. Aspiration J 1 (1): 31-55. 